I have traced the Interglacials, as gravel, sand, and muidy sandbeds, in the Bowbrone, Garpel, and Guelt valleys, to an altitude of 900 feet above sea-level. The shell-beds occur in the parishes of Loudoun, Sorn, Auchenleck, and Colmonell. The Interglacials range from Dalry to Colmonell, and inland to Muirkirk.

MoNkREDDing, KiLWINNING.

Jонn Sмiтн.

April 29th, 1896

\title{
AMMONITES (ACANTHOCERAS) MAMMILLATUM IN THE ISLE OF WIGHT.
}

Sir,-In the Geologrcal Magazine for May, 1896, p. 199 (footnote 2), Mr. R. B. Newton calls attention to Ammonites mammillatum having been recorded from the Chloritic Marl in the Geological Survey Memoir on the Isle of Wight, second edition, p. 279 , and suggests that there is a mistake. In this I think he is probably right. The table in the Memoir was drawn up in such a way as to show the anthority for every fossil. A. mammillatum was inserted on the authority of Captain Ibbetson ("Note on the Geology and Chemical Composition of the various Strata in the Isle of Wight," 1849 , p. 22), who quotes $A$. monile from the Chloritic Marl. A. monile, Sow., according to D'Orbigny (Pal. Franc. Terr. Crét. 1840-1, p. 249), Bronn (Index Pal. 1848, p. 51), and Morris (Cat. Brit. Foss. 1854, p. 297), is A. mammillatum, Schloth. The mistake probably lay in the determination of Ibbetson's specimen as $A$. monile.

12, Marloes Road, Kensington, W.

A. Strathan.

\section{ICE-WORK.}

SIR,-The author of the excellent summary of my book on IceWork (see Grou. MAG. for last month, pp. 228-231) seems to bave misunderstood me in one respect. In regard to the parallel roads of Glenroy, he states-" the objections to a marine origin for these 'roads' are regarded as insuperable." I think that a comparison of pages $94-107$ with pages $163-198$, will show that this is not my opinion. Indeed, I have more than once maintained the contrary. I venture on this correction lest I should be supposed to have changed my mind.

23, Dennivg Road, Havpstead, N.W. IIay $16 t h, 1896$.

T. G. Bonney.

\section{IMISCEIIA.NEOUS.}

Guide to the Musedm of Practical Geology.-The "Descriptive Guide" to this Museum, of which a fourth edition was published in 1877, has long been out of print, and a new edition has been 